\title{
Access law threat to medical merger
}

[SAN FRANCISCO] A shadow has been cast over the planned merger between the medical facilities of the University of California at San Francisco (UCSF) and Stanford University because of public concern about the transparency of decision-making.

Last week, the California state senate approved two bills that would require the two medical schools to comply with the state's laws on open records, open meetings and conflict of interest, making all information on the use of public funds available to the public.

In the past, Stanford has said it will pull out of the merger if such a law is passed, although there are signs that the two universities may be prepared to compromise with the senate's concerns. These will now be debated in the state assembly, which is considering two parallelbills.

The universities have agreed to merge their four hospitals, faculty practice plans and clinics into a private non-profit entity, UCSFStanford Health Care (USHC). The aim is to enhance the survival prospects of the medical facilities in today's 'managed care' marketplace. But there has been growing concern among UCSF faculty members, and others, about the "atmosphere of secrecy" surrounding the new corporation.

State senator John Burton (Democrat, San Francisco), who drafted the bill, said he felt California taxpayers had a right to information on the new corporation's operations, as $\$ 300$ million in public assets would be transferred to USHC. Burton believes that Stanford's threat to back out of the deal is a bluff, because the merger would benefit the university considerably.

Bruce Wintroub, professor of dermatology at UCSF and chief medical officer of the merged company, says the new organization would be a public benefit institution with a public mission. But he argues that it would be hard to compete with other private companies if its plans and records were open for public scrutiny. "We're dealing here in a world of facts, not in a world of wishes," he told a recent meeting of the UCSF academic senate.

At the senate's meeting last week, members said they feared a lack of public accountability could set the stage for a shift to for-profit values and abandonment of both institutions' teaching, research and care-giving priorities. "If the merger goes forward, we become just another healthcare business," said Vishu Lingappa, professor of physiology and medicine.

The senate, made up mainly of tenured, tenure-track and some clinical faculty members, voted 2-to-1 for further investigation of the merger. Many members at the meeting pushed for a vote on a statement supporting or opposing the administration's plans.

A task force set up by the senate to examine research and teaching implications of the merger expressed concerns over the lack of detail in the agreement about promotion and hiring procedures. It claimed that there was also a lack of information about funding for research and clinical teaching, access to patient populations for research and a commitment to open research and faculty independence.

"These concerns have to be nailed down up front, even if it makes us a little less economically competitive," said Svein Oie, professor of pharmacy and chair of the task force.

Lee Goldman, chair of the department of medicine and interim faculty adviser to the USHCboard, told faculty members that many of their concerns had been considered during the merger talks and that the merger would be likely to benefit clinical research. "A core statement in the charter is to fulfil the academic goals of the two institutions," he said. "Either can pull out if unhappy."

But Kenneth Melmon, professor of medicine and molecular pharmacology, and chair of a parallel task force at Stanford, says that none of the new company's decisions shows an understanding that the two institutions distinguish themselves from other health-care providers through their work in basic biology, clinical practice and teaching. Melmon says that faculty members at both schools are collaborating to ensure that principles reflecting a commitment to teaching and research are included in the merger agreement.

Among the areas that need attention are major differences in clinical faculty size, pay, house staff activities and clinical emphasis, says Melmon. UCSF's clinical faculty is four times larger than Stanford's, even though it serves a similar patient population in terms of numbers, acuity and clinical visits.

Stanford has been far more successful than UCSF in technology transfer to commercial enterprises. On the other hand, UCSF spent $\$ 66$ million in unreimbursed costs for indigent care in 1995, while Stanford spent just $\$ 22.2$ million on its unreimbursed adult medical services.

Although it is planned to consolidate specialty units between the two schools, both have strong departments in cancer management, transplantation and other areas that would not easily be absorbed by the other.

According to Robert Wachter, associate chair of the UCSF Department of Medicine, groups from both schools have been meeting to work out quality improvement and practice guidelines that would benefit both schools.

Opponents of the merger say it is unnecessary for the public University of California to provide $\$ 300$ million in assets to a merged entity with Stanford when UCSF's Medical Center achieved a $\$ 21$ million profit in 1995-96.

But supporters say that the schools made modest operating gains only by significantly reducing departmental budgets. Economies of scale and the elimination of duplication will put both schools in a stronger financial position, they argue.

SallyLehrman

\section{Reborn, Captain Cook's ship salls home}

\author{
IMAGE \\ UNAVAILABLE \\ FOR COPYRIGHT \\ REASONS
}

[LONDON] A full-scale replica of Captain

Cook's HMS Endeavour, seen here arriving in its 'spiritual home' of Whitby, is spending seven months touring 15 ports around the United Kingdom before departing for the United States. The ship, which was constructed using original eighteenthcentury plans and documents from the National Maritime Museum, was launched in Western Australia in 1993 by the HM Bark Endeavour Foundation. Richard Ormond, the director of the National Maritime Museum, says that he hopes Endeavour's tour around the United Kingdom will "give the opportunity for people to experience the conditions under which Cook and his men made their breakthrough voyages of discovery". 